\title{
PENDEKATAN KETERAMPILAN PROSES DALAM MENINGKATKAN HASIL BELAJAR BAHASA INDONESIA
}

\author{
Abd. Thalib \\ 1 Universitas Andi Djemma \\ Jl. Sultan Hasanuddin No.13 • (0471) 24506 \\ E-mail: abdul.thalibb@gmail.com
}

\begin{abstract}
This research is a classroom action research. This research was carried out at Ma'arif Makassar Vocational School. This study involved class X students with a total of 30 students. the purpose of this study was to improve the learning outcomes of Indonesian language for students of class X Ma'arif Makassar Vocational High School. This study uses 2 cycles with each one cycle of 3 meetings. Based on the implementation of learning and discussion of the influence of the process skills approach in class X. So the authors can conclude that efforts to improve learning outcomes and student involvement in the learning process in Indonesian subjects can be done with active learning. The results of this study prove that the process skills approach is able to increase student activity and involvement in the learning process and also improve student learning outcomes.
\end{abstract}

Keywords: Indonesian Language, Learning Outcomes, Process Skills.

\begin{abstract}
Abstrak
Penelitian ini adalah penelitian tindakan kelas. Penelitian ini dilaksanakan di SMK Ma'arif Makassar. Penelitian ini melibatkan siswa kelas X dengan jumlah siswa 30 siswa. tujuan penelitian ini adalah untuk meningkatkan hasil belajar bahasa Indonesia pada siswa kelas X SMK Ma'arif Makassar. Penelitian ini menggunakan 2 siklus dengan masing-masing satu siklus 3 kali pertemuan. Berdasarkan pelaksanaan pembelajaran dan pembahasan pengaruh pendekatan keterampilan proses di kelasX. Maka dapat penulis dapat simpulkan bahwa upaya peningkatan hasil belajar dan keterlibatan siswa dalam proses pembelajaran dalam mata pelajaran bahasa Indonesia dapat dilakukan dengan pembelajaran aktif. Hasil penelitian ini membuktikan bahwa pendekatan keterampilan proses mampu meningkatkan aktivitas dan keterlibatan siswa dalam proses pembelajaran dan juga meningkatkan hasil belajar siswa.
\end{abstract}

Kata Kunci,: Keterampilan Proses, Hasil Belajar, Bahasa Indonesia.

\section{PENDAHULUAN}

Permasalahan yang ada dalam dunia pendidikan formal bertambah dari tahun ke tahun. Salah satu permasalahan utama yang dihadapi bangsa Indonesia adalah rendahnya mutu pendidikan formal pada setiap jenjang pendidikan. Usaha telah dilakukan untuk meningkatkan mutu pendidikan nasional, antara lain melalui pelatihan dan meningkatkan kompetensi guru, pengadaan dan alat pelajaran, perbaikan sarana dan prasarana pendidikan 


\section{4 | Abd. Thalib}

dan peningkatan mutu manajemen sekolah. Demikian berbagai indikator mutu pendidikan belum menunjukkan peningkatan yang berarti. Banyak pihak yang mempertanyakan apa yang salah dalam penyelenggaraan pendidikan kita ? dari berbagai pengamatan dan analisis data dan banyak faktor yang menyebabkan mutu pendidikan tidak mengalami peningkatan yang bermakna. Salah satunya yaitu pendekatan yang digunakan di dalam kelas belum mampu menciptakan kondisi optimal bagi berlangsungnya pembelajaran.

Selama ini pendektan yang digunakan adalah pendekatan inputoutput analisis, yaitu pendekatan yang menganggap bahwa input seperti pelatihan guru, pengadaan buku dan alat pelajaran, perbaikan sarana dan prasarana pendidikan lainnya dipenuhi maka pendidikan secara otomatis akan terjadi. Dalam kenyataan mutu pendidikan yang diharapkan tidak terjadi. Mengapa ? karena selama ini pendekatan terlalu memusatkan pada input pendidikan dan kurang memperhatikan proses pendidikan padahal proses pendidikan sangat menentukan output pendidikan.

Salah satu upaya yang dianggap dapat memecahkan masalah tersebut adalah dengan menggunakan keterampilan proses sebagai salah satu metode yang diharapkan dapat melibatkan siswa secara aktif dalam pembelajaran bahasa Indonesia. Keterampilan proses dapat didefenisikan sebagai suatu pendekatan mengajar yang memberikan kesempatan seluasluasnya kepada siswa untuk terlibat aktif dalam proses belajar mengajar sehingga kesempatan untuk mengembangkan diri dan percaya diri dapat ditingkatkan.

Pendekatan keterampilan proses pada hakikatnya adalah suatu pengelolaan kegiatan belajar-mengajar yang berfokus pada pelibatan siswa secara aktif dan kreatif dalam proses pemerolehan hasil belajar (Semiawan, 2002). Pendekatan keterampilan proses ini dipandang sebagai pendekatan yang oleh banyak pakar paling sesuai dengan pelaksanaan pembelajaran di sekolah dalam rangka menghadapi pertumbuhan dan perkembangan ilmu pengetahuan dan teknologi yang semakin cepat dewasa ini.

Pendekatan keterampilan proses akan efektif jika sesuai dengan kesiapan intelektual. Oleh karena itu, pendekatan keterampilan proses harus tersusun menurut urutan yang logis sesuai dengan tingkat kemampuan dan pengalaman siswa. Misalnya sebelum melaksanakan penelitian, siswa terlebih dahulu harus mengobservasi atau mengamati dan membuat hipotesis. Alasannya tentulah sederhana, yaitu agar siswa dapat menciptakan kembali konsep-konsep yang ada dalam pikiran dan mampu mengorganisasikannya. Dengan demikian, keberhasilan anak dalam belajar 
sains menggunakan pendekatan keterampilan proses adalah suatu perubahan tingkah laku dari seorang anak yang belum paham terhadap permasalahan sains yang sedang dipelajari sehingga menjadi paham dan mengerti permasalahannya.

\section{PRINSIP PENDEKATAN KETERAMPILAN PROSES}

Menurut (Semiawan, 2002), terdapat sepuluh keterampilan proses yaitu: (1) kemampuan mengamati, (2) kemampuan menghitung, (3) kemampuan mengukur, (4) kemampuan mengklasifikasi, (5) kemampuan menemukan hubungan, (6) kemampuan membuat prediksi (ramalan), (7) Kemampuan melaksanakan penelitian (percobaan), (8) kemampuan mengumpulkan dan menganalisis data, (9) kemampuan menginterpretasikan data, dan (10) kemampuan mengkomunikasikan hasil.

Kemampuan mengamati, merupakan salah satu keterampilan yang sangat penting untuk memperoleh pengetahuan, baik dalam kehidupan sehari -hari maupun dalam pengembangan ilmu pengetahuan. Kegiatan ini tidak sama dengan kegiatan melihat. Pengamatan dilaksanakan dengan memanfaatkan seluruh panca indera yang mungkin biasa digunakan untuk memperhatikan hal yang diamati, memilah-milah bagiannya berdasarkan kriteria tertentu, juga berdasarkan tujuan pengamatan, serta mengolah hasil pengamatan dan menuliskan hasilnya. Kemampuan menghitung, dalam pengertian yang luas, merupakan salah satu kemampuan yang penting dalam kehidupan sehari -hari dapat dikatakan bahwa dalam semua aktivitas kehidupan manusia memerlukan kemampuan ini.

Kemampuan mengukur sangat diperlukan dalam kehidupan seharihari, dimana seseorang dapat mengetahui sesuatu yang diamatinya dengan mengukur apa yang diamatinya.

Kemampuan mengklasifikasi merupakan kemampuan mengelompokkan atau menggolongkan sesuatu yang berupa benda, fakta, informasi, dan gagasan. Pengelompokkan ini didasarkan pada karakteristik atau ciri-ciri yang sama dalam tujuan tertentu, baik dalam kehidupan seharihari maupun dalam pengembangan ilmu pengetahuan.

Kemampuan menemukan hubungan. Kemampuan ini merupakan kemampuan penting yang perlu dikuasai oleh siswa. Yang termasuk dalam kemampuan ini adalah: fakta, informasi, gagasan, pendapat, ruang, dan waktu. Kesemuanya merupakan variabel untuk mene ntukan hubungan antara sikap dan tindakan yang sesuai. 


\section{6 | Abd. Thalib}

Kemampuan Membuat Prediksi (Ramalan). Ramalan yang dimaksud di sini bukanlah sembarang perkiraan, melainkan perkiraan yang mempunyai dasar atau penalaran. Kemampuan membuat ramalan atau perkiraan yang di dasari penalaran baik dalam kehidupan sehari hari maupun dalam mengembangkan ilmu pengetahuan. Dalam teori penelitian, kemampuan membuat ramalan ini disebut juga kemampuan menyusun hipotesis. Hipotesis adalah suatu perkiraan yang beralasan untuk meneran gkan suatu kejadian atau pengamatan tertentu. Dalam kerja ilmiah, seorang ilmuwan biasanya membuat hipotesis yang kemudian diuji melalui eksperimen.

Kemampuan Melaksanakan Penelitian (Percobaan). Penelitian merupakan kegiatan para ilmuwan di dalam kegiatan ilmiah. Namun, dalam kehidupan sehari-hari penelitian (percobaan) merupakan kegiatan penyelidikan untuk menguji gagasan-gagasan melalui kegiatan eksperimen praktis. Kegiatan percobaan umumnya dilaksanakan dalam mata pelajaran eksakta seperti fisika, kimia, dan biologi. Sedangkan untuk mata pelajaran non eksakta, kegiatan yang biasa dilakukan adalah penelitian sederhana yang meliputi perencanaan dan pelaksanaan.

Kemampuan Mengumpulkan dan Menganalisis Data. Kemampuan ini merupakan bagian dari kemampuan melaksanakan penelitian. Dalam kemampuan ini, siswa perlu menguasai bagaimana cara-cara mengumpulkan data dalam penelitian baik kuantitatif maupun kualitatif.

Kemampuan menginterpretasikan data. Dalam kemampuan ini, siswa perlu menginterpretasikan hasil yang diperoleh karena kemampuan mengkomunikasikan hasil. Kemampuan ini merupakan salah satu kemampuan yang juga harus dikuasai siswa. Dalam kemampuan ini, siswa perlu dilatih untuk mengkomunikasikan hasil penemuannya kepada orang lain dalam bentuk laporan penelitian, paper, atau karangan.

\section{PENERAPAN KETERAMPILAN PROSES}

Semiawan dkk, (1985: 15 -16) merinci alasan yang melandasi perlunya diterapkan pendekatan keterampilan proses dalam kegiatan belajar mengajar sehari-hari :

1. Perkembangan ilmu pengetahuan berlangsung semakin cepat sehingga tak mungkin lagi para guru mengajarkan semua fakta dan konsep kepada siswa. Untuk mengatasi hal tersebut, siswa diberi bekal keterampilan proses yang dapat mereka gunakan untuk memperoleh ilmu pengetahuan tanpa tergantung dar i guru. 
2. Para ahli psikologi umumnya sependapat bahwa anak-anak mudah memahami konsep-konsep yang rumit dan abstrak jika disertai dengan contoh - contoh konkrit, contoh-contoh yang wajar sesuai dengan situasi dan kondisi yang dihadapi, dengan mempraktekkan sendiri upaya penemuan konsep melalui perlakuan terhadap kenyataan fisik, melalui penanganan benda -benda yang benar- benar nyata.

3. Tugas guru bukanlah memberikan pengetahuan, melainkan menyiapkan situasi menggiring anak untuk bertanya, mengamati, mengadakan eksperimen, serta menemukan fakta dan konsep sendiri.

4. Penemuan ilmu pengetahuan tidak bersifat mutlak benar $100 \%$, penemuannya bersifat relatif. Suatu teori mungkin terbantah dan ditolak setelah orang mendapatkan data baru yang mampu membuktikan kekeliruan teori yang dianut. Muncul lagi, teori baru yang prinsipnya mengandung kebenaran yang relatif. Jika kita hendak menanamkan sikap ilmiah pada diri anak, maka anak perlu dilatih untuk selalu bertanya, berpikir kritis, dan mengusahakan kemungkinan-kemungkinan jawaban terhadap suatu masalah. Dengan perkataan lain anak perlu dibina berpikir dan bertindak kreatif.

5. Dalam proses belajar mengajar seyogyanya pengembangan konsep tidak dilepaskan dari pengembangan sikap dan nilai dalam diri anak-anak didik. Konsep disatu pihak serta sikap dan nilai di lain pihak harus dikaitkan. (Semiawan dkk, 1985 : 15-16).

\section{METODE}

Penelitian ini adalah penelitian tindakan kelas yang dilakukan pada bulan september sampai desember 2011. Penelitian dilaksanakan di SMK Ma"arif Makassar melibatkan siswa kelas X dengan jumlah 30 siswa. penelitian ini menggunakan 2 siklus dengan masing-masing satu siklus dengan 3 kali pertemuan. Jadi, pembelajaran dilakukan sebanyak 6 (enam) kali pertemuan. Pada pertemuan I (pertama) pembelajaran dilakukan dengan menyampaikan tujuan pembelajaran dan memberikan motivasi kepada siswa tentang pentingnya materi yang akan disajikan. Pada pertemuan II (dua) pembelajaran dilakukan dengan mengajukan masalah keterampilan proses dan memberikan kesempatan kepada siswa untuk mengeluarkan pendapat, yang pada akhirnya diperoleh sebuah kesimpulan. Pada pertemuan yang III (tiga) pembelajaran dilakukan dengan memantabkan pemahaman siswa dengan tentang sub pokok bahasan dan siswa diarahkan untuk mengerjakan soal. Pada pertemuan IV (empat) pembelajaran dilakukan dengan membahas ulang secara singkat pembelajaran yang dilakukan, kemudian 


\section{8 | Abd. Thalib}

siswa dibimbing untuk membuat rangkuman. Pada pertemuan VIII (delapan) pembelajaran dilakukan dengan guru memberikan tugas kepada siswa untuk mengerjakan soal-soal pada buku paket masing-masing secara individu. Pada pertemuan VI (enam) pembelajaran dilakukan dengan memantau aktifitas siswa selama pembelajaran berlangsung untuk memantau peningkatan minat siswa dalam belajar.

Secara garis besar, tahapan pembelajaran dibagi menjadi 2 tahap yaitu tahap pra pembelajaran dan tahap pembelajaran. Pada tahap pra pembelajaran, beberapa hal yang dilakukan antara lain: pertama, pemberian angket motivasi. Kegiatan ini dimaksudkan untuk mengetahui motivasi awal. Skala yang digunakan dalam penyusunan angket motivasi belajar adalah skala Likert dengan menggunakan skala

1-5. Angket motivasi belajar sistem dirumuskan berdasarkan indikator: (1) perhatian (attention), (2) keterkaitan (relevance), (3) kepuasan (satistaction), dan (4) keyakinan (confidence). Angket motivasi diberikan untuk mengukur hasil belajar bahasa Indonesia siswa dan angket ini disusun sendiri oleh guru. Skala motivasi awal nantinya akan digunakan sebagai pembanding terhadap skala hasil belajar setelah siswa mendapat perlakuan atau tindakan pembelajaran (motivasi akhir).

Kedua, pembentukan kelompok belajar. Pengelompokan ini dilakukan secara bebas melalui metode hitungan satu sampai lima atau enam dan siswa yang mendapatkan hitungan yang sama bergabung dalam satu kelompok sehingga terbentuk kelompok yang heterogen baik dari segi kemampuan akademis maupun latar belakang jenis kelamin dan lainnya.

Tahap selanjutnya adalah tahap pembelajaran. Langkah utama yang dilakukan adalah: pertama, perencanaan pembelajaran. Beberapa hal yang dilakukan pada perencanaan pembelajaran ini meliputi: (1) menetapkan rancangan dalam proses belajar dengan menggunakan pendekatan keterampilan proses. (2) membuat skenario pembelajaran dengan menggunakan pendekatan keterampilan proses. (3) membuat lembar observasi untuk melihat kondisi proses belajar mengajar berlangsung di kelas ketika pendekatan keterampilan proses diaplikasikan. (5) melaksanakan teks akhir untuk melihat perkembangan siswa setelah menerapkan pendekatan keterampilan proses.

Kedua. Pelaksanaan pembelajaran. (1) kegiatan awal. Guru mengawali pertemuan dengan mengecek kehadiran siswa. selanjutnya menyampaikan tujuan pembelajaran. Guru memberikan motivasi kepada siswa tentang pentingnya yang disajikan. (2) kegiatan inti. Pengembngan ; guru mengawali kegiatan dengan mengajukan masalah keterampilan proses. Jika pengetahuan materi siswa belum cukup untuk menjawab masalah tersebut, maka guru membimbing siswa kearah jawaban yang benar atau 
menjelaskan materi yang belum dipahami siswa. guru memberikan pekerjaan kepada siswa secara berkeliling. Kemudian guru memberikan pertanyaan lanjutan lalu mendorong siswa untuk mebuat kesimpulan dari jawaban yang bervariasi, sampai pada kesimpulan yang diinginkan. Guru selalu memantau belajar siswa, untuk mengetahui apakah materi yang diberikan sudah dipahami.

Siswa diberi kesempatan untuk bertanya dan meminta penjelasan guru. Penerapan; untuk memantapkan pemahaman siswa tentang sub pokok bahasan, maka siswa diarahkan untuk mengerjakan soal latihan. Lalu guru meminta salah seorang siswa mengerjakan di papan tulis, agar siswa yang belum paham dapat tertolong dan termotivasi untuk belajar. Penugasan kepada siswa untuk menyelesaikan soal di papan tulis, dilakukan secara bergantian sehingga setiap siswa mempunyai kesempatan yang sama untuk mendapatkan tugas. (3) kegiatan akhir. Review; guru membahas ulang secara singkat pembelajaran yang dilakukan, kemudian siswa dibimbing untuk membuat rangkuman.

Ketiga. Pengamatan (observasi). Observasi dilakukan terhadap pelaksanaan tindakan dengan menggunakan lembar observasi yang telah disiapkan. Observasi dilakukan dengan tujuan agar memperoleh informasi yang lebih mendasar dan komprehensif tentang data aktivitas siswa, motivasi dan suasana pembelajaran dilakukan mulai dari awal sampai akhir pembelajaran. Data hasil observasi tersebut digunakan untuk mengetahui kelemahan dan kelebihan pelaksanaan pembelajaran pada pertemuan berikutnya.

Keempat, refleksi. Pada akhir siklus diadakan refleksi terhadap hal-hal yang diperoleh baik dari hasil observasi dan evaluasi dikumpul kemudian dianalisis. Kekurangan-kekurangan yang telah terjadi pada siklus pertama diperbaiaki pada siklus berikutnya.

\section{HASIL PENELITIAN}

JSesuai dengan tahapan pelaksanaan pembelajaran pendekatan keterampilan proses, pelaksanaan tindakan dimulai dengan penyajian pengantar materi tentang standar kompetensi menampilkan perilaku yang sesuai dengan nilai-nilai Pancasila secara klasikal. Dalam penyajian materi ini guru bertindak sebagai pengajar menjelaskan standar kompetensi yang akan dipelajari. Penjelasan dimaksudkan agar pemikiran siswa tertuju pada materi tersebut dan lebih mendalami materi tersebut dengan melihat langsung buku paket yang dimiliki siswa. Kegiatan ini berlangsung sekitar 15 menit. 


\section{0 | Abd. Thalib}

Setelah siswa mengelompok pada kelompoknya masing-masing, peneliti kemudian menugaskan siswa untuk berdiskusi dan berbagi peran dalam kelompok

secara demokratis. Hasil diskusi dari masing-masing kelompok tersebut harus dikumpulkan pada akhir pembelajaran. Selama kegiatan kerja kelompok yang berlangsung kurang lebih 60 menit, guru selalu mengawasi, mengamati, dan memfasilitasi kelompok. Kegiatan ini diselesaikan oleh siswa dalam waktu dua kali pertemuan.

Setelah setiap kelompok menyelesaikan hasil diskusi pendekatan keterampilan proses terhadap hasil belajar, mereka menampilkan perilaku yang sesuai dengan nilai-nilai Pancasila, rangkaian kegiatan berikutnya adalah presentasi sub-sub metode pendekatan ketrampilan proses yang telah dibuat. Kegiatan presentasi kelompok ini selalu diakhiri dengan tanya jawab. Kegiatan ini dipandu dengan lembar format presentasi yang telah disiapkan oleh guru. Lembar tersebut merupakan salah satu alat untuk menilai aktivitas siswa dalam presentasi. Kelompok yang telah menyelesaikan presentasi diberi latihan soal dan pengayaan. Hal ini dimaksudkan untuk memperkuat pemahaman siswa sambil menunggu kelompok lain yang belum menyelesaikan tugasnya.

Kegiatan diakhiri dengan tes individu. Tes ini dilakukan secara serentak dan ditempatkan dalam satu kelas. Bentuk tes yang digunakan adalah soal pilihan ganda dengan alokasi waktu 60 menit. Skor hasil tes akhir tersebut kemudian diolah untuk dapat dijadikan salah satu indikator peningkatan pemahaman siswa sebagai hasil belajar metode pendekatan keterampilan proses. Dari hasil tes diperoleh informasi bahwa ketuntasan belajar siswa mencapai 95\% sedangkan yang belum memenuhi standar ketuntasan mencapai $5 \%$.

Setelah pelaksanaan tes individu, dilakukan wawancara terhadap siswa yang dalam hal ini tidak mengalami peningkatan dari nilai tes awal dengan tes akhir. Oleh karena itu, materi wawancara pada kesempatan ini berkisar pada penyebab tidak adanya peningkatan pengetahuan. Dari hasil wawancara tersebut diperoleh beberapa informasi bahwa tidak terjadinya peningkatan nilai ini disebabkan oleh: (1) siswa belum terbiasa belajar kooperatif (kelompok) sehingga terkadang siswa bingung dengan situasi belajar dalam kelompoknya, (2) siswa merasa tidak bertanggung jawab dalam menyelesaikan keseluruhan tugas yang diberikan sehingga tidak jarang siswa acuh tak acuh terhadap tugas yang diberikan, dan (3) siswa merasa canggung dan rendah diri dalam memulai diskusi karena siswa merasa tidak mempunyai kontribusi penting dalam menyelesaikan tugas kelompok.

PiJIES: Pedagogik Journal of Islamic Elementary School 
Selain wawancara, peneliti juga melakukan observasi. Berdasarkan hasil observasi diperoleh beberapa informasi antara lain: (1) suasana kelas cukup kondusif. Siswa dalam kelompok tampak cukup interaktif dan agak ramai namun tidak saling mengganggu dan kestabilan belajar berjalan dengan baik dalam pembelajaran pen- dekatan keterampilan proses. (2) Siswa tampak lebih aktif di dalam kelompok masing-masing. Namun, masih ada juga siswa tertentu yang agaknya kurang cepat mengerjakan karena ada kebingungan untuk menentukan sub-sub konsep yang harus dituliskan. (3) Siswa lebih berani mengungkapkan pendapat mereka baik kepada teman dan guru yang sebelumnya mereka takut untuk mengungkapkannya. (4) Terjadi pembagian tugas pada masing-masing anggota kelompok dengan baik. Namun, masih ada yang merasa tersisihkan dan diam saja tanpa melakukan apa -apa. (5) Aktivitas dan motivasi siswa semakin meningkat dengan diterapkannya metode pendekatan ketrampilan proses ini.

Melihat fakta yang terjadi selama pembelajaran, maka peneliti melakukan refleksi pembelajaran. Berikut adalah hasil refleksi yang dilakukan: (1) sebagian siswa sudah menunjukkan sikap positif dalam belajar metode pendekatan keterampilan proses, seperti membantu memahami materi yang dipelajari, dan saling mendorong untuk belajar. Namun demikian, masih ada siswa yang sulit menerima pembelajaran tersebut. Siswa merasa canggung dan agak bingung karena dia merasa malas membaca dan kurang bisa mengungkapkan ide-idenya dalam presentasi kelompok. (2) Semua subjek mengikuti kegiatan pembelajaran dengan tenang dan tertib. (3) Interaksi antara guru secara periodik dapat meningkatkan semangat belajar siswa sehingga tidak terjadi kemacetan kegiatan diskusi dan pendekatan ketrampilan proses dalam kelompok. (4) Siswa perlu didorong dan dimotivasi secara terus menerus agar mau bertanya, khususnya pada pembahasan metodde pendekatan keterampilan proses dan tanya jawab dalam pelaksanaan presentasi. (5) metode pendekatan keterampilan proses memang baik, akan tetapi memerlukan manajemen waktu yang baik agar pembelajaran yang berlangsung tidak menggangu pelajaran yang lain.

Dalam proses belajar banyak faktor yang dapat mempengaruhi hasil belajar, salah satu diantaranya adalah pendekatan keterampilan proses yang digunakan dalam pembelajaran. Pendekatan yang menempatkan siswa sebagai penerima informasi dapat meminimalkan aktivitas siswa dalam pembelajaran. Hal ini dapat terlihat pada pembelajaran kompetensi dasar sebelumnya. Perubahan pola pembelajaran dan lingkungan belajar yang kurang lazim bagi subjek penelitian sebelumnya ternyata mempengaruhi hasil belajar siswa. Selama pelaksanaan pembelajaran pada pertemuan 


\section{2 | Abd. Thalib}

pertama hasil belajar siswa dalam hal ini melalui metode pendekatan keterampilan proses tergolong masih rendah, bahkan ada subjek yang bekerja sendiri-sendiri atau diam saja tanpa melakukan apapun. Kalaupun terjadi diskusi masih dalam intensitas rendah dan terkadang kerjasama yang dibangun hanya sebatas teman yang akrab.

Kenyataan di atas dapat dimaklumi mengingat siswa belum pernah belajar dengan model pembelajaran tersebut. Jadi ketika mereka dihadapkan pada situasi pembelajaran metode pendekatan keterampilan proses yang di dalamnya terdapat anggota dengan kemampuan yang heterogen mereka mengalami kesulitan dalam melaksanakannya sehingga pembelajaran masih belum sesuai dari yang diharapkan.

Memasuki pertemuan II pembelajaran melalui metode pendekatan keterampilan proses mengalami peningkatan dan siswa mendapat kesempatan mengungkapkan idei-denya. Mereka mempunyai keberanian untuk mengungkapkan pendapat atau idenya di dalam kelompok.

Guru dalam pembelajaran ini berusaha untuk menggali dan merangsang pembentukan ide, pengujian ide, dan penguasaan konsep dengan cara mengajukan pertanyaan dan mengemukakan masalah yang muncul dan berusaha menggunakan ide-ide yang telah dikemukakan oleh siswa serta memberikan penguatan dalam bentuk pujian. Namun demikian, pada pembelajaran ini masih mengalami hambatan antara lain anak-anak masih merasa bingung dan takut untuk mengungkapkan idenya.

Dalam pembelajaran ini terlihat interaksi antar teman dan terlihat keakraban secara lebih dini sehingga mereka lebih dapat menyesuaikan diri dengan teman kelompoknya dan terjadi komunikasi. Dengan komunikasi yang berarti meningkatkan pula kemampuan bahasa yang mendorong orang berpikir. Keakraban merupakan faktor pendukung terbentuknya suasana diskusi kelompok dan kerjasama yang dinamis. Hal ini dikarenakan ketika siswa merasa aman, positif dan merasa diperhatikan, hormon serotonin dan dopamin akan meningkat dan berpengaruh pada mood, memori dan motivasi untuk belajar (Rustan, 2017). Berkaitan dengan hal ini Suparno (2000) menyatakan bahwa agar hubungan kawan dapat memberi pengaruh yang positif atau konstruktif, mereka harus mengusahakan suasana saling memiliki, saling membantu, dan saling memperhatikan satu sama lain.

Selain itu, bentuk tugas dalam lembar kegiatan juga ternyata mempengaruhi intensitas interaksi langsung subjek. Tugas yang terstruktur secara teoritis dapat mempengaruhi proses kelompok dalam mencapai keefektifan kerja mereka. Kondisi demikian memberikan kesempatan bagi siswa untuk berdiskusi, berdebat mengemukakan 
pendapat, dan mendengarkan pendapat orang lain sehingga memungkinkan mereka menemukan cara dan teknik memproses informasi dalam membangun gagasan baru.

Hasil dari pembelajaran bentuk tugas tersebut adalah lebih intensifnya aktivitas baik diskusi dengan kelompok maupun diskusi dalam kelas, sehingga suasana kelas bisa menjadi lebih hidup. Kegiatan tersebut seperti sharing pendapat, saling membantu dalam belajar, dan memberi dorongan kepada teman. Dengan diberikan suatu bentuk pertanyaanpertanyaan dan bentuk tugas yang memerlukan pemikiran yang kritis siswa tidak hanya dapat bertanya atau menjawab, tetapi juga sudah mulai dapat menghargai konstribusi, menggunakan kesepakatan, mengambil giliran, dan mampu mempertahankan idenya.

Hasil analisis siswa yang diberikan sebelum pelaksanaan tindakan menunjukkan bahwa rata-rata hasil belajar siswa adalah 2,85 dengan kategori cukup baik. Kondisi demikian tentu saja dipengaruhi oleh berbagai faktor. Hasil analisis terhadap hasil belajar yang diberikan setelah selesainya penerapan pembelajaran melalui pendekatan keterampilan proses menunjukkan bahwa terjadi peningkatan hasil belajar. Kategori tersebut menunjukkan bahwa penerapan pendekatan tersebut dalam pembelajaran bahasa Indonesia mampu meningkatkan hasil belajar siswa.

Peningkatan hasil belajar seperti diatas dimungkinkan antara lain karena selama pelaksanaan tindakan siswa lebih banyak terlihat dalam pembelajaran karena peneliti memberikan kesempatan kepada siswa untuk berani mengungkapkan ide dan peneliti juga berusaha untuk merangsang siswa untuk berpikir dengan memberikan berbagai contoh hasil industri. Stimulasi persuasi verbal yang diberikan dapat meningkatkan efikasi diri siswa sehingga termotivasi untuk berusaha menyelesaikan tugas yang sedang dikerjakan siswa (Thaha \& Rustan, 2017). Siswa yang termotivasi untuk belajar akan sangat tertarik dengan berbagai tugas belajar yang sedang mereka kerjakan, menunjukkan ketekunan yang tinggi, dan variasi aktivitas belajar merekapun lebih besar.

Hasil yang dicapai siswa pada tes akhir sudah cukup baik. Dengan ratarata tersebut masih ada siswa yang belum mengalami peningkatan hasil belajar secara tuntas. Namun demikian dalam pembelajaran sebaiknya penerapan suatu pendekatan dan penggunaan metode pembelajaran juga harus memperhatikan karakteristik materi pelajaran. 


\section{4 | Abd. Thalib}

\section{PENUTUP}

Berdasarkan hasil pelaksanaan pembelajaran dan pembahasan pada pelaksanaan penerapan pembelajaran pendekatan keterampilan proses di kelas X SMK Ma"arif Makassar, maka dapat penulis simpulkan bahwa upaya peningkatan hasil belajar dan keterlibatan siswa dalam proses pembelajaran dalam mata pelajaran bahasa Indonesia dapat dilakukan dengan menerapkan metode pendekatan keterampilan proses. Dalam pelaksanaannya di kelas metode tersebut dapat dipadukan dan dikembangkan dengan berbagai media dan alat peraga pembelajaran yang disesuaikan dengan materi/tema yang dipelajari dan pembagian alokasi waktu yang telah ditetapkan sebelumnya. Sehingga terbukti bahwa metode pendekatan keterampilan proses mampu meningkatkan hasil belajar dan keterlibatan siswa dalam proses pembelajaran.

Berdasarkan hasil penelitian, ada beberapa hal yang perlu diperhatikan secara seksama. Pertama, perlu untuk terus dikembangkan dan diterapkannya metode- metode pembelajaran yang dapat meningkatkan hasil belajar siswa di antaranya adalah melalui metode pembelajaran pendekatan keterampilan proses. Kedua, perlunya peran dari semua pihak di lingkungan sekolah untuk menerapkan metode pembelajaran tersebut menjadi pola pembelajaran yang sehari-hari dapat diterapkan di sekolah. Pelaksanaan pembelajaran tersebut tidak harus ditunjang dengan peralatan dan alat peraga pelajaran yang mahal, tetapi dengan perlengkapan dan alat peraga pembelajaran yang sederhana pun dapat berjalan dengan lancar.

Ketiga, perlunya sosialisasi adanya metode pembelajaran pendekatan keterampilan proses kepada guru mata pelajaran lain agar mereka juga dapat menerapkannya sebagai salah satu upaya untuk meningkatkan hasil belajar siswa dalam pembelajaran.

Keempat, perlunya dilakukan penelitian yang lebih lanjut untuk mengembangkan penerapan metode pembelajaran pendekatan keterampilan proses sebagai salah satu alternatif untuk meningkatkan hasil belajar siswa, serta untuk mengubah perilaku siswa yang cenderung dominan.

\section{DAFTAR PUSTAKA}

B. Uno, Hamzah. 2009. Perencanaan Pembelajaran. Jakarta : Bumi Aksara. Budiningsih, Asti. 2008. Belajar Dan Pembelajaran. Jakarta : Rineka Cipta. A.M, Sudirman.1968. Interaksi dan Motivasi Belajar Mengajar. Jakarta : Rineka Cipta. 
Simanjuntak, Lisnawati, 1993. Metode Mengajar Bahasa Indonesia. Jakarta : Rineka Cipta.

Sriyono, 1992. Teknik Belajar Mengajar Dalam CBSA. Jakarta : Rineka Cipta. N. K, Roestiyah, 2001. Strategi Belajar Mengajar. Jakarta : Rineka Cipta. Ridarta, Made, 1997. Landasan Pendidikan. Jakarta : Rineka Cipta.

Rustan, E. (2017). Learning Creative Writing Model Based on Neurolinguistic Programming. International Journal of Language Education and Culture Review, 3(2), 13-29. https:/ / doi.org/ 10.21009/ IJLECR.032.02

Thaha, H., \& Rustan, E. (2017). Orientasi Religiusitas dan Efikasi Diri dalam Hubungannya dengan Kebermaknaan Pendidikan Agama Islam pada Mahasiswa IAIN Palopo. Studi Agama Dan Masyarakat, 13(2), 163-179. https:/ / doi.org/ 10.23971/ jsam.v13i2.551 
36 | Abd. Thalib

Halaman ini sengaja dikosongkan

PiJIES: Pedagogik Journal of Islamic Elementary School 